\title{
Effect of Job Security and Governance on Teacher's Job Satisfactions of Higher Educational Institutions in Southern Punjab
}

\author{
Amir Saif, Muhammad Adnan \\ National College of Business Administration and Economics (NCBA\&E), Multan, Pakistan \\ amirsaif9001@gmail.com
}

\begin{abstract}
Educational institutes in Pakistan have become progressively successful. In the last few decades Pakistan is facing tremendous challenges particularly in education and due to insufficient and ineffective public education system. However, there is need to plan and strategize upcoming challenges bases on education machinery workforce placement, capability and capacity. This study is aiming to examine the relationship between, job security, governance, and teacher's job satisfaction. In addition this study is also investigating the moderating effect of leadership style between job security and governance. This study has used SMART-PLS structural equation modeling to analyze the data using quantitative research method. This study has used quantitative research method using stratified sampling technique. This study had used 266 completed and usable questionnaires collected from teacher of the institutions in Sothern Punjab- Pakistan. The findings have indicated a significant relationship between job security, governance and job satisfaction at educational institution level. In addition it was also reveals that leadership style has no significant influence between job security, governance and teacher's job satisfaction. The influence of these factors calls for the further research. There is also need to carry out a similar but comparative study in rural settings.
\end{abstract}

Keywords: Job security, governance, leadership style, job satisfaction.

\section{Introduction}

Human resource is foremost asset of any institute as the academic and non-academic employees are main contributors for the success of universities, colleges or schools. All those perspectives should be kept in mind which can motivate an employee towards achieving his objective and goals. Efficiency of an employee is all about employee's duties, obligation and processes for achieving goals (Sumra, 2005). Performance of employee should be measured and sustained on regular basis. Job satisfaction describes about employee whether he/she is quantifiable as well as particular towards his job. Many companies are focusing on measurement of job satisfaction feature as it is a very important factor. Job satisfaction is sort of modern phrase. In previous centuries a single person implied on the specific job defined employee's job or work performed through the work of employee's parents. Number of variety of factors affects the job satisfaction of any person. Some factors are characterized as rewards, pay, environment of company, administration, influence of public, job tasks assigned, job clarity and hub design etc. If, the employees are happy at their jobs, they are satisfied and more pleased. Job designed should be such that it ultimately enhances the satisfaction of employee. Job design should be included the job enrichment, job rotation as well as job enlargement (Brkich, et al., 2002).

In addition teachers are called to work on weekends and even on holidays during the high work pressure. In addition, there are few authors (Smith \& Wang 1996) who have identified that the most important factor which makes the teacher dissatisfied is their job security, governing authority and leadership styles. As in some cases due to institutes weak profitability and bad performance the employees are downsized. The educational institutes are always in the bargaining position with the employees and the old employees can always be replaced with new fresh employees on contractual basis paying fewer salaries. The human resource department among educational institutes in Pakistan has great importance and institutes realize its meaning for their performance is rising with the passage of time. Universities and institutes are looking for competitive candidates and provide them market equivalent compensation to retain them and remain them as their satisfied employees. Improve students academics performance, university should ensure that academic staff is satisfied their job and deliver excellent job performance in the class (Yee, 2018). Table 1 is showing the statistics of total institutes and teachers distribution from the year 2013 to 2016 issued in a report presented by ministry of finance. This data is indicating a slow growth of established institutes and new teacher's appointments. 
Table 1: Number of Mainstream Institutes and Teachers by Level (Thousands)

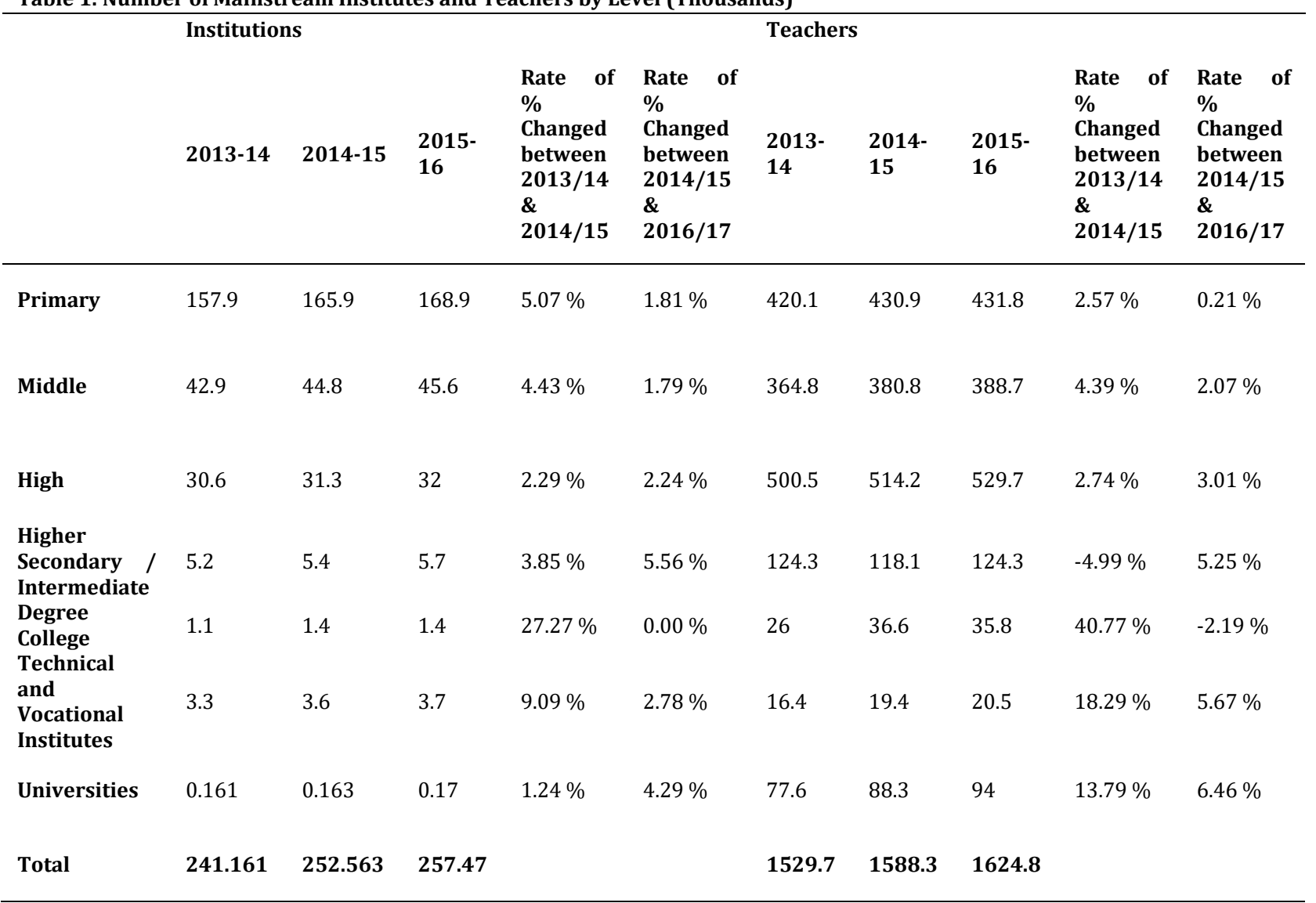

Source: Ministry of Professional \& Technical Training, AEPAM, Islamabad (2017),

Problem Statement: Internationally and in Asia economies are growing rapidly and core myth is capability building via education. Educational institutes in Pakistan have become progressively successful. In the last few decades Pakistan is facing tremendous challenges particularly in education and due to insufficient and ineffective public education system, private education is sufficiently filling those opportunities and making tremendous profits (Saeed, Ahmad, Salam, Badshah, \& Ali, 2013). Although the public and private education is transforming and adding value to the system but still the teacher's job security, institutes governance and leadership styles remains a question for debate. This phenomenon has stimulated a number of investigators to study the changes in organizational structures, governance and leadership behavior (Smith \& Wang 1996). The literature Vecchio, (2002) has identifies that workload among teachers in Pakistani private institutes is very high and teachers are expected to work more than stipulated working hours. In addition, policy for pay increment and promotion is very slow and it dissatisfies the employees According to Luthans, (2005) changing duty timings and location also dissatisfies the teachers (Rose, 2000).

Research Objective: Given below are the research objectives of this study:

- To investigate the relationship between job security and teacher's job satisfaction.

- To find the relationship between governance and teacher's job satisfaction.

- To investigate the moderating factor of leadership style between job security, governance and teacher's satisfaction.

Research Question: Given below are the research questions of this study: 
- Does job security influence teacher's job satisfaction in public and private educational institutions in southern Punjab?

- What is the relationship between governance and teacher's job satisfaction in public and private educational institutions in southern Punjab?

- Does leadership style moderate between job security, governance and teacher's satisfaction?

\section{Literature Review}

Job Satisfaction: The organization considers and used many tools for satisfaction of employee like as job security, work place, targets etc. Raza et al. (2015) found that job satisfaction of teacher is a predicted by teacher retention, determine of teacher commitment in turn contribution to school effectively. According to Hall, (1996) study less satisfied employee has more intention and tendency to leave the organization. Definition of job satisfaction is employee reaction about his organization or occupation. Job satisfaction is gratification or positive emotional state resulting from a review of one's job or job experience (Akdol \& Arikboga, 2015). Moreover, Dogan (2016) found that job satisfaction could be improves by communication among colleagues. The author added that good rewarding system, working environment, organizational governance, job security and promotion can also make the employees satisfied.

Job Security: Many researchers have find that job security induce organization commitment of employees (Davy, 1997) investigate that job security significantly relate to employee satisfaction. Iverson (1996) find that job security has significant impact on organization commitment. Job security significant has expanded and high light in the previous ten years feedback of employees why they change the organization. Raza et al. (2015) found that academic staff commitment is influenced by various factor but there are two major factors, (i) job security and (ii) job satisfaction. Job security is one's expectation related still in job situation. Job security is important part of job commitment (Akpan, 2013). Consequently, it may be hypothesized:

Hypothesis \# 1: There is a significant positive relationship between job security and job satisfaction among teachers in HEI.

Governance: Governance is a system by way the companies makes their strategies and implements these strategies to achieve the goals of the firms. After corporate scandals like Enron and the big financial losses, the codes of corporate Governance globalized all over the world to protect the investor from frauds of directors and management Bernard (2014). Bernard, (2014) informed that "Corporate governance involves a set of relationships between a company's management, its board, its shareholders and other stakeholders. Corporate governance also provides the structure through which the objectives of the company are set, and the means of attaining those objectives and monitoring performance are determined." Affiliation between Good Corporate Governance and Job Satisfaction Literature on corporate governance shows that, no existing empirical studies on the relationship between corporate governance and employee job satisfaction has been reported. How between corporate governance and firm performance exist. Subsequently, it may be hypothesized:

Hypothesis \# 2: There is positive association between governance and job satisfaction of teacher in HEI.

Leadership Styles: Leader plays a very important role in any organization and do have long-lasting and important impact on operation of any organization. According to Elpers and Westhuis, (2008) mostly leaders are less concerned about practices they are performing and their effect on satisfaction of their employees. Leaders have to deal with employee in organization to get some complete from them so leaders have to adopt some behaviors to deal with people in organization. (Lewin, et al., 1939) did explore the different leadership styles as laissez-faire leadership, autocratic and democratic styles. Therefore, it may be hypothesized:

Hypothesis \# 3a: Leadership styles moderates the association between job security and job satisfaction of teacher in HEI.

Hypothesis \# 3b: Leadership styles moderates the association between governance and job satisfaction of teacher in HEI. 
Figure 1: Conceptual Framework

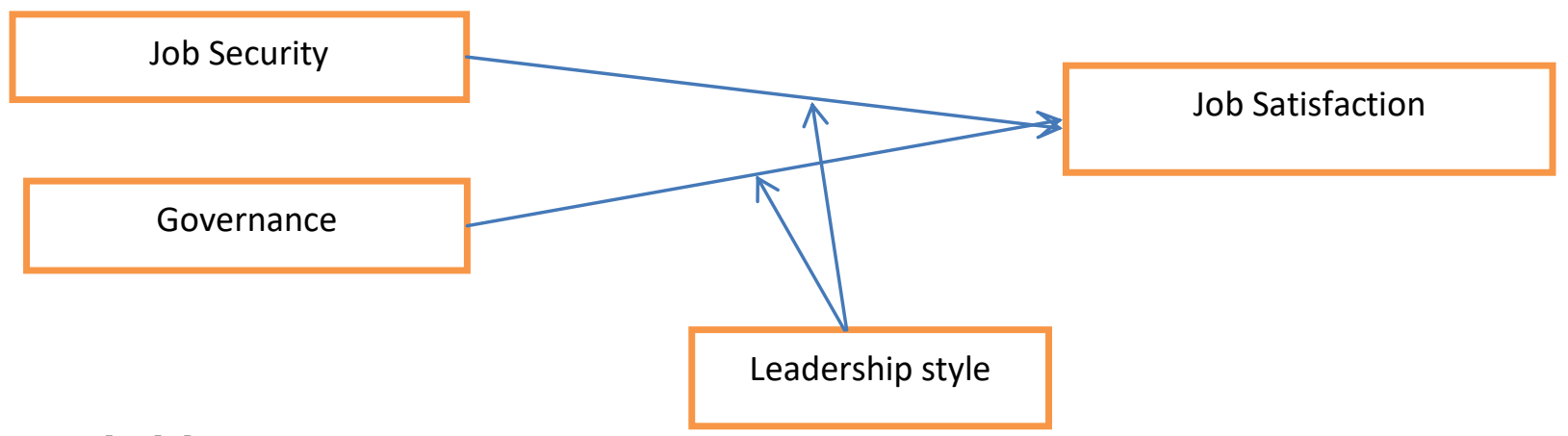

\section{Methodology}

Our study is on impact of job security, governance and leadership styles influencing the job satisfaction in the teacher's Southern Punjab. For this study quantitative research method was used to collect the data. Three hundred and thirty (350) questionnaires were distributed via mailed, email, and personal interaction to the teacher of the institutions Sothern Punjab. The total number of questionnaires distributed was 330, out of which only 290 of questionnaires which were finally returned. Therefore the response rate was $81 \%$ (refer to table 2 and 3 ).

Sample Size: According to Sakran (2012) population sampling table if the population is between 1000, to 2000 the required sample should be 350 samples. Study sample includes of 350 respondents of different of different institution. Sampling method that is used in study is convenience random sampling because respond depends on their availability and willingness.

Sampling Technique: Due to analyze us use the non-probability test has been around utilized. For the reason that clarification of the analysis is not just to solve the particular magnitude of impact of factor within institution, however comparatively to acknowledge a new effects, consequently a new non-probability test is actually good enough (Sakran 2012) random sampling technique for collection sampling.

Unit of Analysis: The unit of analysis is the main entity that is being analyzed in research. It is the 'what' or 'who' that is being studied. In social science research, typical units of analysis include individuals (most common), groups, social organizations and social artifacts. In this study unit of analysis are teachers from private universities, colleges and schools.

Table 2: Population Table

\begin{tabular}{llllll}
\hline S. No & Name of Private Institute & Private & Public Institute & Total & Percentage (\%) \\
\hline 1 & Universities & 3 & 13.000 & 16.000 & 1.0 \\
2 & Colleges & 1500 & 200.000 & 1700.000 & 77.0 \\
3 & Schools & 5000 & 1005.000 & 6005.000 & 272.0 \\
Total Population & & & $\mathbf{7 7 2 1 . 0 0 0}$ & 350 \\
\hline
\end{tabular}

Table 3: Response Rate

\begin{tabular}{lll}
\hline S. No & Items & Responses \\
\hline 1 & Total Number of Questionnaire Distributed & 330 \\
2 & Total Number of Questionnaire Returned & 290 \\
3 & Questionnaire as missing value & 2 \\
4 & Incomplete Questionnaires & 18 \\
5 & Non- serious filled questionnaires & 4 \\
6 & Total Usable Questionnaire & 266 \\
Response Rate & $\approx \mathbf{8 1} \%$ \\
\hline
\end{tabular}




\section{Analysis Measurement Model}

The assessment of the measurement model contain of reliability and validity calculation. Glocker, (2012) informed that measurement models can be evaluated according to factor loadings of more than 0.7 (refer to Table 4 for more details) and composite reliability criteria need to be higher than 0.6 is measured as internal consistency (Henseler, 2012). Meanwhile, the Average Variance Extracted (AVE) standard the average variance have to be higher than 0.5 and the results demonstrates that each AVE value is above 0.5 level (ranges from 0.9630 to 0.965 and refer to figure 2 for more details). In addition Table 1 shows the Cronbach's Alpha value of governance (0.9959), job security (0.99588), leadership style and job satisfaction (0.99629) were all considered acceptable to be tested which mostly found to be more than 0.7 benchmark (also refer to Table 4).

Table 4: Summary of Measurement Model

\begin{tabular}{|c|c|c|c|c|c|c|c|c|}
\hline Variables & Items & $\begin{array}{l}\text { Actual } \\
\text { Loading }\end{array}$ & AVE & $\begin{array}{l}\text { Composite } \\
\text { Reliability }\end{array}$ & R Square & $\begin{array}{l}\text { Cronbach's } \\
\text { Alpha }\end{array}$ & Communality & Redundancy \\
\hline \multirow{10}{*}{$\begin{array}{l}\text { Governan } \\
\text { ce }\end{array}$} & GOV1 & 0.981221 & 0.965 & 0.996386 & & 0.995969 & 0.964998 & \\
\hline & GOV10 & 0.981497 & & & & & & \\
\hline & GOV2 & 0.986549 & & & & & & \\
\hline & GOV3 & 0.985093 & & & & & & \\
\hline & GOV4 & 0.978258 & & & & & & \\
\hline & GOV5 & 0.977749 & & & & & & \\
\hline & G0V6 & 0.982709 & & & & & & \\
\hline & GOV7 & 0.984275 & & & & & & \\
\hline & GOV8 & 0.983 & & & & & & \\
\hline & GOV9 & 0.983044 & & & & & & \\
\hline \multirow[t]{10}{*}{$\begin{array}{l}\text { Job } \\
\text { Security }\end{array}$} & JS1 & 0.983057 & 0.96425 & 0.996306 & & 0.99588 & 0.964249 & \\
\hline & JS10 & 0.98371 & & & & & & \\
\hline & JS2 & 0.98198 & & & & & & \\
\hline & JS3 & 0.981776 & & & & & & \\
\hline & JS4 & 0.981523 & & & & & & \\
\hline & JS5 & 0.979958 & & & & & & \\
\hline & JS6 & 0.980426 & & & & & & \\
\hline & JS7 & 0.983256 & & & & & & \\
\hline & JS8 & 0.981101 & & & & & & \\
\hline & JS9 & 0.982825 & & & & & & \\
\hline \multirow{12}{*}{$\begin{array}{l}\text { Job } \\
\text { Satisfactio } \\
\text { n }\end{array}$} & & & & & & & & \\
\hline & JSAT1 & 0.986925 & 0.96424 & 0.996639 & 0.998233 & 0.99629 & 0.964235 & 0.56604 \\
\hline & $\begin{array}{l}\text { JSAT1 } \\
0\end{array}$ & 0.98024 & & & & & & \\
\hline & $\begin{array}{l}\text { JSAT1 } \\
1\end{array}$ & 0.981071 & & & & & & \\
\hline & JSAT2 & 0.981193 & & & & & & \\
\hline & JSAT3 & 0.9818 & & & & & & \\
\hline & JSAT4 & 0.979506 & & & & & & \\
\hline & JSAT5 & 0.980195 & & & & & & \\
\hline & JSAT6 & 0.984844 & & & & & & \\
\hline & JSAT7 & 0.980735 & & & & & & \\
\hline & JSAT8 & 0.982798 & & & & & & \\
\hline & JSAT9 & 0.982168 & & & & & & \\
\hline
\end{tabular}




\begin{tabular}{|c|c|c|c|c|c|c|}
\hline \multirow[t]{10}{*}{$\begin{array}{l}\text { Leadershi } \\
\text { p Styles }\end{array}$} & LEDS1 & 0.984749 & 0.96349 & 0.996225 & 0.995788 & 0.963493 \\
\hline & $\begin{array}{l}\text { LEDS1 } \\
0\end{array}$ & 0.984908 & & & & \\
\hline & LEDS2 & 0.982328 & & & & \\
\hline & LEDS3 & 0.981043 & & & & \\
\hline & LEDS4 & 0.983302 & & & & \\
\hline & LEDS5 & 0.984258 & & & & \\
\hline & LEDS6 & 0.974063 & & & & \\
\hline & LEDS7 & 0.975469 & & & & \\
\hline & LEDS8 & 0.980028 & & & & \\
\hline & LEDS9 & 0.985548 & & & & \\
\hline
\end{tabular}

Figure 2: Measurement Model

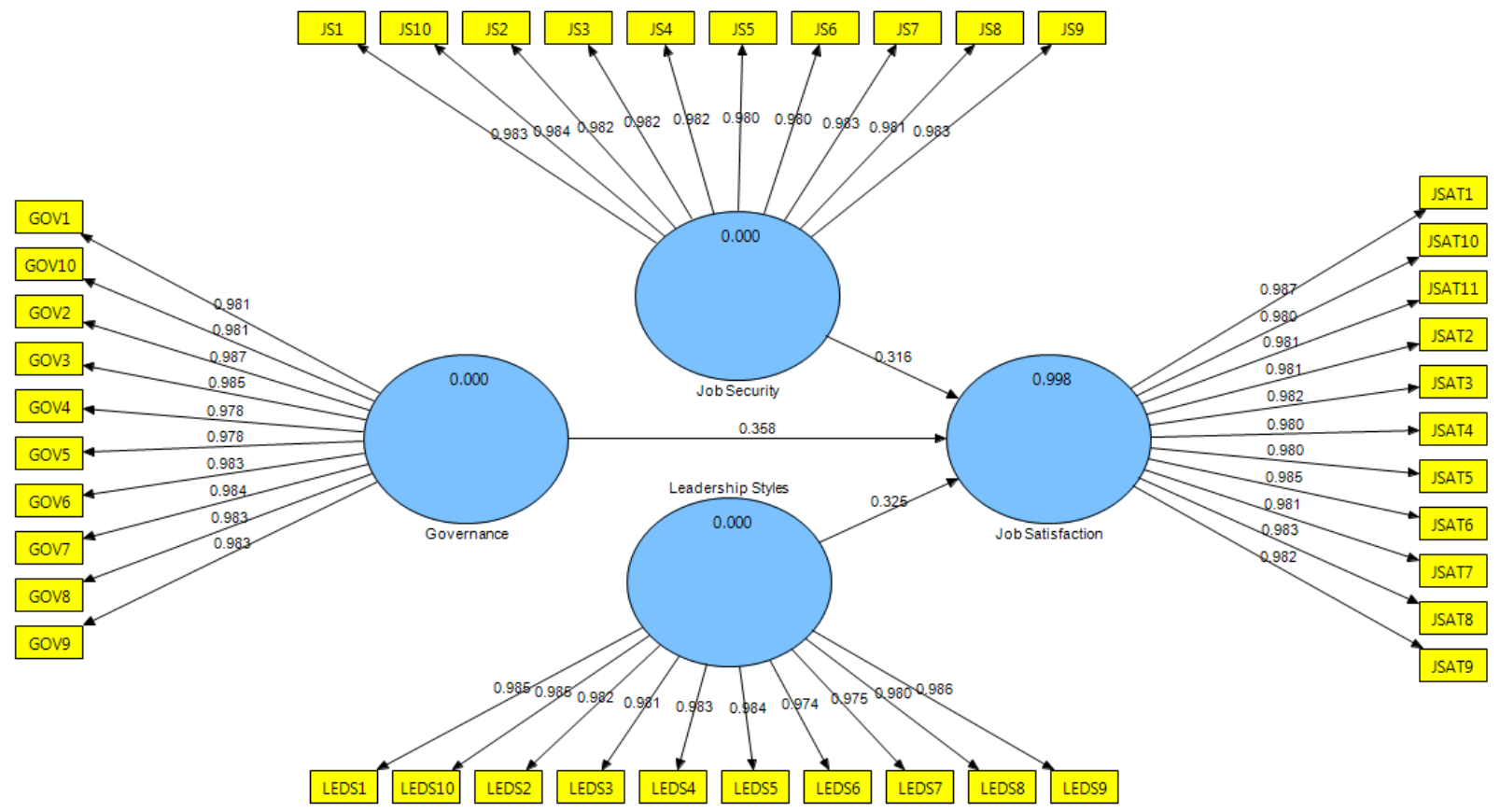

Discriminant Validity: Fornell and Larcker (1981) recommend that the square root of Average Variance Extracted (AVE) in every latent variable can be used to form discriminant validity, if this assessment is larger than other correlation values amongst the Latent Variables. The Fornell-Larker standard measures how each item relates to each construct (Chin, 1998). Consequently, Table 5, discriminant validity was formed in which the square root of AVE is manually calculated and written in bold on the diagonal of the table which shown that all the constructs with a value of AVE more than 0.5. In addition, entirely constructs also had the diagonal values of square root of more than the square correlation with other constructs in off-diagonal. Thus, this has showed that all constructs come across the satisfactory standard of discriminant validity (Henseler et al., 2009; Osman, Ismail, Nowalid, \& Adnan, 2014).

Table 5: Discriminant Validity

\begin{tabular}{lllll}
\hline & Governance & Job Satisfaction & Job Security & Leadership Styles \\
\hline Governance & $\mathbf{0 . 9 8 2 3 4 3 1 2}$ & & & \\
Job Satisfaction & 0.998547 & $\mathbf{0 . 9 8 1 9 5 4 6 8 3}$ & & \\
Job Security & 0.998651 & 0.998721 & $\mathbf{0 . 9 8 1 9 6 1 8 1}$ & \\
Leadership Styles & 0.9979 & 0.998465 & 0.998609 & $\mathbf{0 . 9 8 1 5 7 6 7 9 3}$ \\
\hline
\end{tabular}




\section{Findings of Structural Model}

H1: Job Security has a Significant Effect on Job Satisfaction: There is important correlation between job security and job satisfaction $(\mathrm{t}=5.349144, \mathrm{p}<0.05)$ because $\mathrm{t}$-statistic is greater than 1.96 (refer to table 3 ). The relationship between the job security and the job satisfaction is the positive. Similarly, Dachapalli and Parumasur (2012) confirmed that opinion of high job security is linked frequency to increase the level of job satisfaction among staffs. When dissatisfaction of job security exists, employees afraid that they may dismiss one day and it will persuade their job satisfaction and less retention to stay at institution (Sverk, et al., 2002).

H2: Governance has a Significant Effect on Job Satisfaction: The results of the Smart-PLS show there is important association between Governance and job satisfaction ( $t=4.729237, p<0.05)$ because $t$-statistic is greater than 1.96. It's indicated, governance has significant association with job satisfaction. A good governance system is positively association with job satisfaction of teachers (Bernard et al., 2014).

\section{Table 6: Hypothesis Testing (Direct Relationships)}

\begin{tabular}{llllllll}
\hline $\begin{array}{l}\text { Hypothesis } \\
\text { Testing }\end{array}$ & Relationship & $\begin{array}{l}\text { Original } \\
\text { Sample } \\
\text { (O) }\end{array}$ & $\begin{array}{l}\text { Sample } \\
\text { Mean } \\
\text { (M) }\end{array}$ & $\begin{array}{l}\text { Standard } \\
\text { Deviation } \\
\text { (STDEV) }\end{array}$ & $\begin{array}{l}\text { Standard } \\
\text { Error } \\
\text { (STERR) }\end{array}$ & $\begin{array}{l}\text { T Statistics } \\
\text { (|O/STERR|) }\end{array}$ & $\begin{array}{l}\text { Acceptance } \\
\text { / Rejection }\end{array}$ \\
\hline H1 & $\begin{array}{l}\text { Governance } \\
\rightarrow\end{array}$ & & & & & & \\
& $\begin{array}{l}\text { Job } \\
\text { Satisfaction }\end{array}$ & 0.435212 & 0.402668 & 0.092026 & 0.052026 & 4.729233 & Accepted \\
& $\begin{array}{l}\text { Job Security } \\
\text { H2 }\end{array}$ & & & & & & \\
& $\begin{array}{l}\text { Job } \\
\text { Satisfaction }\end{array}$ & 0.564096 & 0.49512 & 0.105455 & 0.05455 & 5.349144 & Accepted \\
& & & & & & \\
\hline
\end{tabular}

\section{Conclusion}

Drawn the conclusion of this paper in which the job security, governance, leadership style and job satisfaction of teaching staff. Similarly the important difference in which related contribution of job security and job satisfaction of educational staff commitment, with the job security being the most potent participation fellow by job satisfaction. It would be deduced that institution staff that experience job satisfaction are expected to reveal high institution job commitment. The same would be appropriate with lecturer who observes their job as being secure. Therefore, job security and job satisfaction are two related the concept of effect of job attitude institutional commitment of institution staff. The governance is also significant associated with job satisfaction of teacher due $\mathrm{t}$-value is greater than 1.96 .

So it is show association between the governance and job satisfaction. This study which shows the no affect the leadership style on teacher job satisfaction with other factors, if we improving the leadership style relate to improvement work efficiency of the academic staff. Educational leader is very important to aware of how leadership styles affect teacher's job satisfaction because they might influence on student progress. This study has also shown the relationship of governance, job security influence the overall job satisfaction. Similarly, they have very important role implication for human resource management practice and administrations of institution conductive social atmosphere need to be produced in the working position to develop assurance of teachers. 


\section{Figure 3: Structural Model}

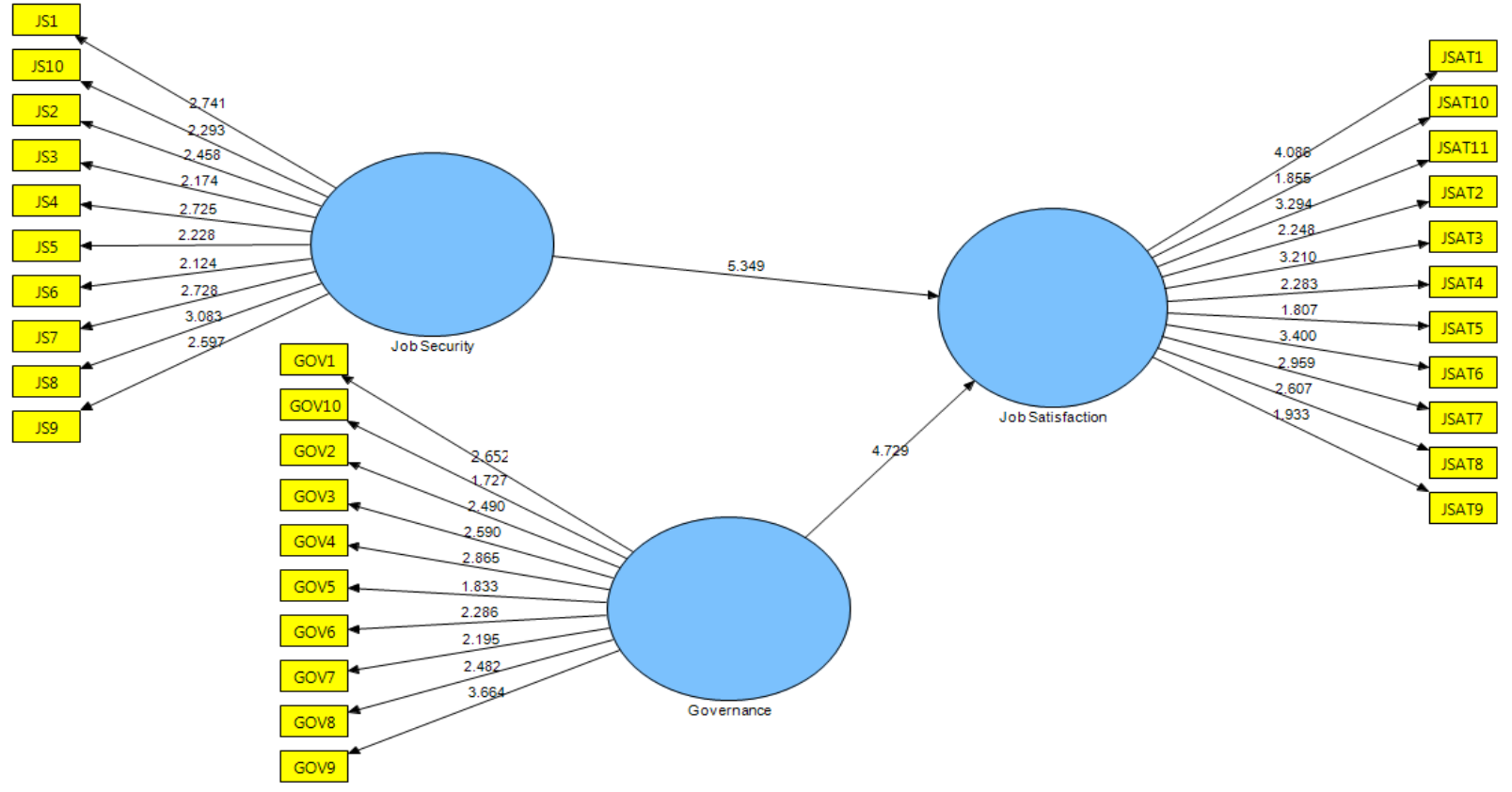

\section{Moderation}

Hypothesis \# 3a: Leadership styles moderates the association between job security and job satisfaction of teacher in HEI.

Hypothesis \# 3b: Leadership styles moderates the association between governance and job satisfaction of teacher in HEI.

The moderating role of leadership style is no significance association between the job security, governance and the job satisfaction because T-value is less 1.96 similarly p-value is greater from 0.05 . So this shows no intervention between the above variable. However, Kenkelvin (2017) the principle leadership style becomes one of the central factors to consider because they a play vital role in organizations. The study sought to find the effects of leadership style on teacher satisfaction in private and public institution. Crispen (2017) indicates in his study academics professionals were not satisfied with leader support those received in relevant department.

Table 7: Moderation

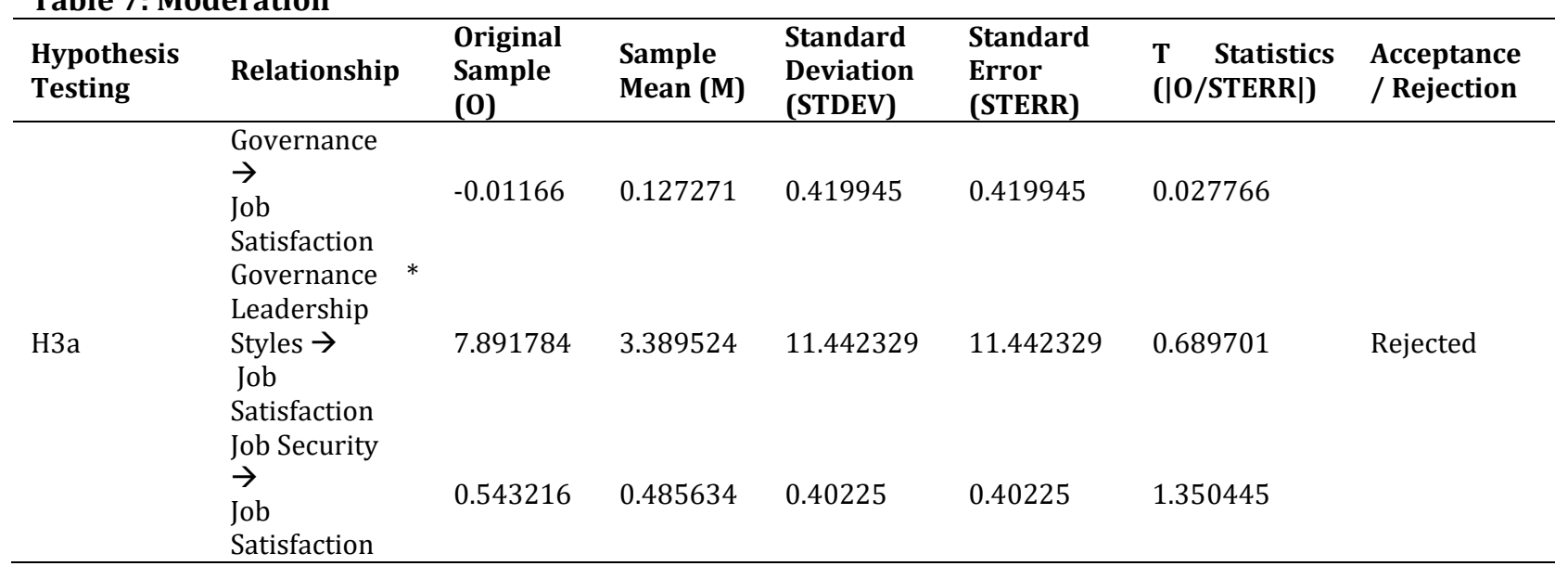




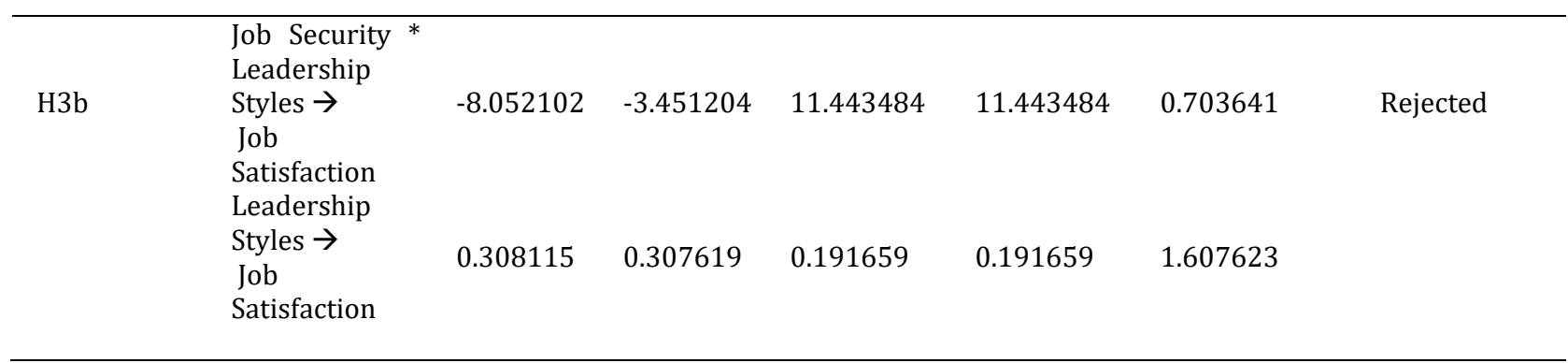

Figure 4: Moderations

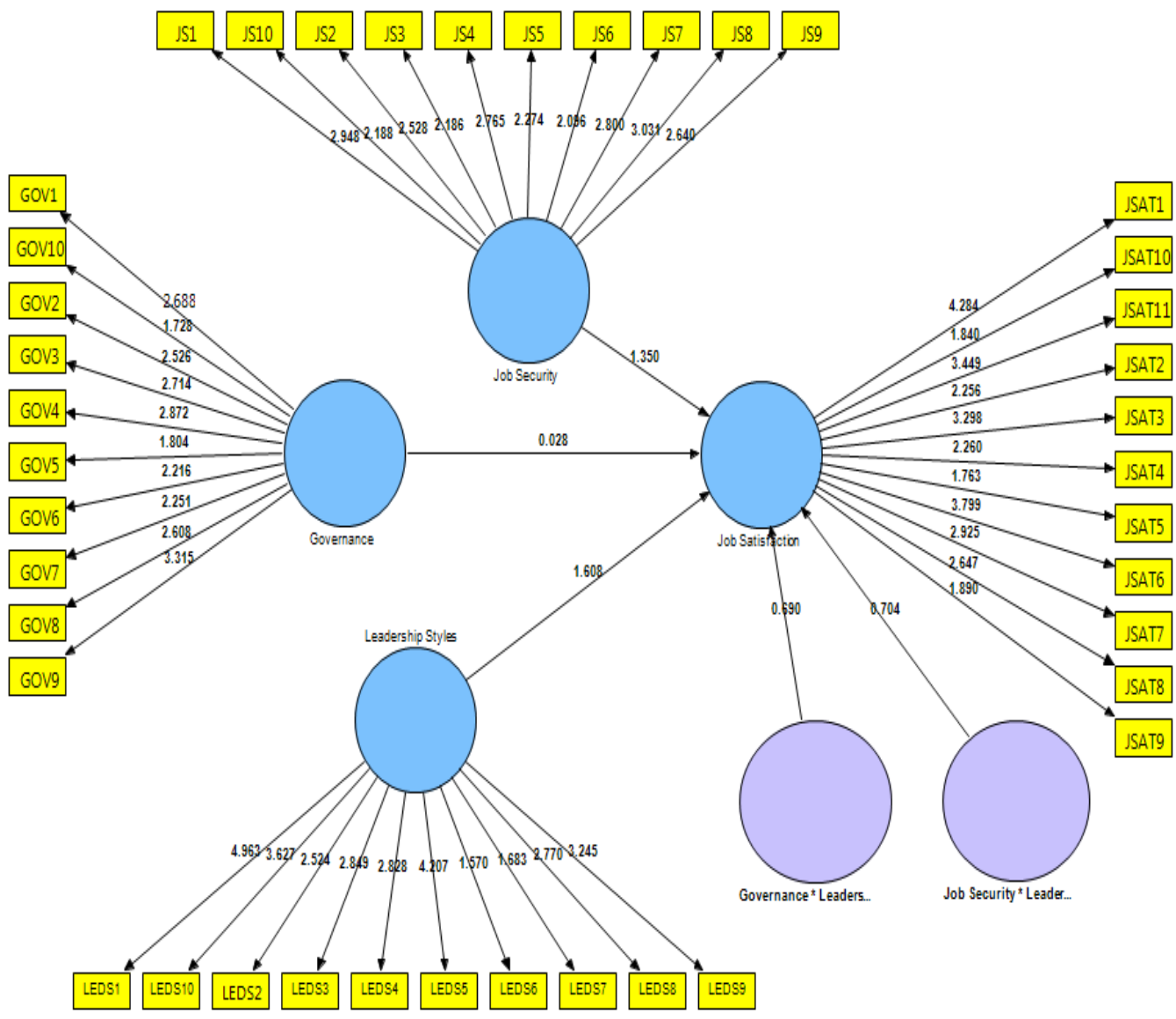

Theoretical Contribution: This is conceptually contributed to knowledge but explaining the phenomenon of employee pay and promotion, job security, work load, governance, leadership among teachers influencing their job satisfaction. There are very few studies which ponder on the subject matter discussing teachers human resource related issues leading to their satisfaction attributes.

Methodological Contribution: Furthermore this research in one of its kindly exclusively:

A. Using teachers as respondents in Southern-Punjab.

B. Collecting data from 350 teachers was really a big challenge and this research has contributed by collecting required sample as per sampling collection technique.

C. The research has used SPSS for running frequencies and investigated the validity, reliability (measurement model) and hypothesis testing (structural model) using Smart-PLS, which is also a contribution in a since that it's a new statistical approach.

Recommendations: On the finding of this paper, author recommended the below suggestions: 
A. A parallel study is carry out in a business atmosphere to build the role of customers in improving employee commitment Future study is suggested for involvement of other social participants in education such as parents and institutional management boards and committee.

B. Then the study was conducted in urban areas teachers would have been committed to their working institutions due to other suitability such as convenience to their working station and teacher residential status and preferences. The impact of these above factors call for further research. There is also need to carry out a similar but comparative study in rural setting.

\section{References}

Akdol, B. F. \& Arikboga, S. (2015). The effect of leader behavior on job satisfaction: A research on technology fast 50 turkey companies. Social and behavior science, 195, 278-282.

Akpan, C. P. (2013). Job Security and Job Satisfaction as Determinants of Organizational Commitment among University Teachers in Cross River State, Nigeria British Journal of Education, 1(2), 82-93.

Bernard, N. N. (2014). Good Corporate Governance and Employee Job Satisfaction: Empirical Evidence from the Ghanaian Telecommunication Sector, International Journal of Humanities and Social Science, $4(13)$.

Brkich, M., Jeffs, D. \& Carless, S. A. (2002). A global self-respect measure of person job fit European. Journal of psychological Assessment, 18(1), 43-51.

Chin, W. W. (1998). The partial least squares approach to structural equation modeling. In G. A. Marcoulides (Ed.), Modern methods for business research, 295-358.

Crispen, C. (2017). Organizational culture and job satisfaction among academic professionals at a South African university of technology, Problems and Perspectives in management, 15(2).

Dachapalli, P. L. \& Parumasur, S. B. (2012). Employee susceptibility to experience job insecurity, South African Journal of Economic and Management Science, 15(1), 31-43.

Davy, j. A., Kinicki, A. J. \& Scheck, C. L. (1997). A test of job security direct and medicated effects on withdrawal cognition. Journal of organization Behavior, 18(4), 224-249.

Dogan, Al. (2016). The Comparison of the Individual Performance Levels Between Full-Time and Part-Time Employees: The Role of Job Satisfaction.12th International Strategic Management Conference, ISMC 2016, 28-30 October 2016, Antalya, Procedia - Social and Behavioral Sciences, 235, 382-391.

Elper, k. \& Westhuis, D. J. (2008). Organization leadership and its impact on social workers job satisfaction: A national study. Administration in social work, 32(3), 26-43.

Fawad, H., Mohd Azwardi Bin Md Isa. \& Mohammad Basir Bin Saud. (2016). The moderating effect of business size Between SME's networking and export Performance: a different point of view of ModeprobeSPSS and Smart PLS. Journal of Global Business and Social Entrepreneurship (GBSE), 1(2), 79-91.

Fornell, C. \& Larcker, D. F. (1981). Structural equation models with unobservable variables and measurement error: Algebra and statistics. Journal of marketing research, 382-388.

Fornell, C. \& Larcker, D. F. (1981). Evaluating structural equation models with unobservable variables and measurement error. Journal of Marketing Research, 18(1), 39-50.

Glocker, T. (2012). Partial Least Squares Path Modeling: Introduction and Application.

Hall, V. (1996). Dancing on the ceiling; a study of women managers in education, London; Paul Chapman Publishing.

Henseler, J. (2012). PLS Path Modeling with Smart PLS. Foundations, Applications, Extensions, Advances. Inforte Seminar Jyvaskyla.

Henseler, J., Christian, M., Ringle R., R. \& Sinkovics. (2009). The use of partial least squares path modeling in international marketing. New challenges to international marketing. Emerald Group Publishing Limited, 277-319.

Iverson, R. D. (1996). Employee acceptance of organization change; the role of organization commitment. International Journal of Human Resource management, 7(1), 122-149.

Kenkelvin, K. (2017). Influence of principle of leadership styles on teacher job satisfaction in public secondary school in Maro South- sub country Kenya. Internal journal of education and Research, 5(9).

Lewin, K., Lippitt, R. \& White, R. K. (1939). Patterns of aggressive behavior in experimentally created social climate. Journal of social Psychology, 10, 270-299.

Luthans, F. (2005). Organization behavior, New York: McGraw-Hill. 
Osman, L. H., Ismail, A., Nowalid, W. A. W. M. \& Adnan, N. H. (2014). Empirical Study of the Relationship between Consumer and. Journal of WEI Business and Economics, 5(1), 33-38.

Raza, M. Y. M., Akhtar, W., Mudassir, H. \& Saeed A. M. (2015). Impact of intrinsic Motivation on employee's satisfaction, Journal of Management and Organizational Studies.

Rose, M. (2000). Future tense? Are growing occupation more stressed out and depressive? University of bath. ESRC Working paper 3, Work Centrality and careers project: Bath.

Saeed, M., Ahmad, I., Salam, M., Badshah, R. \& Ali, S. (2013). Critical Analysis of Problems of School Teachers in Pakistan: Challenges and Possible Solutions. Journal of Education and Practice, 4(4), 7.

Sakran, U. (2012). Research Method, $7^{\text {th }}$ edition New York Johan Wily \& Sons.

Smith, P. B. \& Wang, Z. M. (1996). Chinese leadership and organizational structures. In Bond, M. H. (Ed), the handbook of Chinese psychology, 322-337.

Sumra, S. (2005). The living and working condition of teacher: A Research Report. Dar es Salaam, HakiElimu.

Sverk, M., Hellgren, J. \& Naswall, K. (2002). No security: A meta-analysis and review of job insecurity and its consequence, Journal of Occupational Heath Psychology, 7(3), 242-264.

Vecchio, R. P. (2002). Preference for idealized styles of supervision the leadership quarterly, 13(6), 643-671.

Yee, L. C. (2018). An Analysis on the Relationship between Job Satisfaction and Work Performance among Academic Staff in Malaysian Private Universities. Journal of Arts \& Social Sciences, 1(2), 64-73. 